\title{
Bonded Logistic Center: Policy Analysis on Perspective Supply Side Tax Policy on Shipyard Industry
}

\author{
Haula Rosdiana \\ Department of Administrative Science \\ Universitas Indonesia \\ Depok, Indonesia \\ h.rosdiana@ui.ac.id
}

\author{
Inayati, Maria R.U.D. Tambunan, Murwendah \\ Department of Administrative Science \\ Universitas Indonesia \\ Depok, Indonesia
}

\begin{abstract}
The aim of this article is to examine government fiscal policy which establish Bonded Logistic Center (BLC) as an alternative of offering conventional fiscal incentives by using Supply-side Tax Policy perspective. This study also compares the implementation, advantages and disadvantages of conventional fiscal incentives and Bonded Logistic Centre on shipyard industry. This research occupies mix method approach. The data is collected through literature review, in-depth interview whereas then the simulation of industry transaction is occupied as quantitative aspect. The research found that based on Supply Side tax policy perspective the establishment of Bonded Logistic Centre is more efficient for the cost of taxation aspect, compare to that of conventional fiscal incentives which has to be applied on individual entity bases. In addition, establishing Bonded Logistic Centre seem more beneficial for the logistic cost aspect, administrative and bureaucracy procedures.
\end{abstract}

Keywords-fiscal policy; fiscal incentives; Bonded Logistic Center; supply side tax policy

\section{INTRODUCTION}

The government effort to enhance maritime industry by implementing cabotage principle seems has not been successful enough indicated by the massive supply of used ship produced by local and foreign company. This practices has become pressure for local shipyard since they cannot compete in the shipping market due to the large inflow of used ship in Indonesia shipping market ${ }^{1}$ [1]. The situation may be worsened by high logistic cost in Indonesia compare to Thailand and Malaysia during 2007-2016 ${ }^{2}$ whereas shipyard industry has to pass several value chains to construct new ship from kinds of components and spare parts [2].

Insufficient component and raw materials produced by local company and the need of sophisticated technology enforce the local shipyard to import them which are up to $65 \%$ from total needed. Large number of importation lead to high cost of import and liability and customs duty. Shipyard

\footnotetext{
${ }^{1}$ The increase unit of ship went up to $120 \%$ in 2014 since 2005 whereas local production was nearly $20 \%$

Based on World Bank publication about Logistic Performance Index in ASEAN 2007-2016, Indonesia is in the fourth place or higher than Singapore (1), Malaysia (2) and Thailand (3).
}

business has to pay 5\%-15\% of import tax and duty for each importation of component. This cost lead to higher cost of local ship production compare to imported ones thus local product hardly compete in shipping market.

The government commitment to promote maritime industry specifically to develop the competitiveness and productivity has begun to realize by the release of Economic Policy Package II. The Economic policy package focuses on friendly investment climate by offering less bureaucratic permit, tax incentives and the availability of logistic center through the release of Government Regulation No. 69/2015 that essentially change the Value-Added Tax (VAT) liability that is VAT treatment of imports and deliveries of certain means of transport and services related to it from VAT exemption to VAT not-collected [3], [4]. Regarding national industry competitiveness, the government also has provided customs duty incentives with the form of Customs Duty Paid by Government. However, both instrument is still ineffective due to administrative and bureaucratic hassle. Series of procedures to apply the incentive distort the goals of offering incentives.

To lessen bureaucratic procedure and dwelling time of importation as the spirit of Economic Package II, the government has been establishing Bonded Logistic Centre. Indonesia Investment Coordinating Board (2016) emphasizes that Bonded Logistic Centre (BLC) is expected to lower domestic logistic costs thus it can improve Indonesia's competitiveness particularly on the ground of investment that currently has to compete with other prominent South Asian countries.

\section{DISCUSSION: EXAMINING FISCAL POLICIES ON MARITIME INDUSTRY - ADVANTAGES AND CONSTRAINTS}

Tax incentives is a common selected instrument of government to reduce economic burden of the investors as an attraction tools. According to UNCTAD (2000), tax incentive can be defined as any incentives that reduce tax burden of business to induce them investing in particular projects or sector [5]. The incentives can occupy income tax, value added tax, tariff or other state levies. Conceptually, there are two 
types of VAT incentives, (i) VAT exemption and (ii) zero rate. Tait (1988) defines that "exemption actually means the entrepreneur has to pay the VAT input of acquired goods without being able to claim or calculate the credit for the paid tax on his input against the output tax of goods sold" whereas zero rate means that the entrepreneur is fully compensated for any VAT he says on input or it simply can be said the entrepreneur is taxed $0 \%$ of its input goods thus in the credit mechanism of output tax (tax on goods sold) against input tax (tax on acquired goods) lead to overpayment tax [6]. Thus, the entrepreneur is eligible to apply for tax refund.

This basic concept of VAT incentives might be developed by tax policy maker in particular country for the purpose of practical implementation. For example, in Indonesia zero rate has been applied with the forms; non-collected VAT and VAT paid by government. In the adoption of VAT incentives in Indonesia besides zero rate and its variety developed form, the government also has ever applied VAT exemption. Both type of this incentives has advantages and disadvantages in its practical application. All the incentives have to applied individual entity basis.

VAT exemption incentives for shipping industry has been applied in 2000 through the release of Government Regulation No.146/2000 (GR-146) which solely applied for importation of spare parts for national commercial shipping industries and national fishing industry [7]. This regulation has not clearly governed whether the incentive offered would applied for government institutions other than the ones that has been stipulated on the regulation and for ship-related industry which has not hold shipping license (In Indonesia is called "SIUPAL") for example shipyard industry; shipbuilding and ship repairing. Thus, this policy for Indonesia context cannot be utilized by shipyard industry or partially it is only beneficial for parts of maritime industry chain.

In conceptual basis, the disadvantage of VAT exemption incentive is that the VAT input become the component cost of goods sold, so the cascading effect of taxation cost involve in the selling price but for obligation fulfillment of the tax administrative compliance to the tax authority, this type of incentive is more simple than that of zero rate. For Indonesia context for instance, in order to be granted the incentives, business industry only needed to released invoice that has been stamped with sign "VAT exempted based on GR No. 146 year 2000 as lastly amended by Presidential Regulation No. 28 year 2003". The printed stamp on the invoice would be released immediately after receiving the letter confirming VAT exemption facility for supply of taxable goods/service applied for each importation. Then the transaction would be reported in monthly VAT return.

The last application of zero rate in Indonesia is with the form of VAT paid by government through the release of Ministry of Finance Regulation No. 193/PMK.03/2015 [8] and Ministry of Finance Regulation No. 192/PMK.03/2015 (PMK193 and PMK-192) [9]. Economically, this type of incentives can reduce the entrepreneur tax burden since they are eligible to get VAT refund. Thus, cost for VAT can be reallocate for other productive activities. However, for the fulfillment of administrative compliance, this incentive on its nature is quite complicated because the government has to established a monitoring system to ensure that the incentives is used properly by the targeted business sector. Probably for advance bureaucracy institution with integrated database and sophisticated technology, setting up a monitoring system with less administrative burden is not a big deal. The situation will be different if the less advance institution has to deal with this problem. In practice, the incentives even lead to high administrative cost because of administrative procedure thus the incentives distort the business to apply for incentives since the burden to some extend outweigh the benefit.

The situation in which considerable administrative burden of granting VAT incentives happened in Indonesia. To have VAT incentive facilities, business actors or shipyard entrepreneurs have to submit the proposal to be granted Official Letter of Non-Collectible VAT (or in Indonesia is called Surat Keterangan Tidak Dipungut or "SKTD"). The proposal to get SKTD to be attached with Importation Planning. The Importation Planning (In Indonesia is called Rencana Kebutuhan Impor dan Perolehan or "RKIP") describes the types, number and detail specification of equipment that will be imported for next one fiscal year. Most of shipyard industry could not perform this kind of technical regulation, since the production activity for example ship building and ship repairing is based on job order from shipping industries. For several cases, few number of welldeveloped shipyard probably will be able to provide RKIP in the beginning of fiscal year, however it will be the case for infant shipyards, especially if they receive docking and repairing job order. It tends to unpredictable the specification of needed components if they perform docking and repairing job in the mid of the year that mostly they have to complete the job in relatively short period of time. In addition, to the realization report of VAT incentives from the business to the government bear new problem because the series of tax audit that will spend another cost.

Besides VAT incentive mechanism, customs duty incentives are also offered by the government. Basically, the tariff of custom duty has been determined by World Trade Organization (WTO) that is called most favored nations but the reduced rate may apply if a country ratify international trade cooperation with other jurisdiction to set lower rate for certain goods that is known as preferential tariff. Another possible mechanism of reduce rate is through domestic interfere called rebates, remission and suspensions [10]. Most of the challenge in the implementation of customs duty incentives is the availability of data base system and reliable monitoring that commonly happen in developing countries but it remains as favorite policy choice [11].

Indonesia government adopt customs duty incentives as instrument to support industrial development including for maritime sector. Indonesia applied another type of customs duty incentives differed from the general, it is customs duty paid by government. In practice, the government allocate amount as tax expenditure for each fiscal year. The amount of tax expenditure allocated from National Tax Revenue and Expenditure will be examined based on several economic 
considerations thus the amount of incentives to be granted for the industry will be different for each year.

To get the facilities, business practitioner has to pass series of procedure. The procedure is as follow:

TABLE I. The PRocedure to APPly Customs Duty INCENTIVES AND CUSTOMS DECLARATION SETTLEMENT

\begin{tabular}{|c|c|c|c|c|c|c|}
\hline & Business & $\begin{array}{l}\text { Technical } \\
\text { Ministry }\end{array}$ & $\begin{array}{l}\text { Directorate of } \\
\text { Ministry of Fin }\end{array}$ & $\begin{array}{l}\text { ustoms and } 1 \\
\text { nce }\end{array}$ & xxcise & \\
\hline \multirow[t]{2}{*}{$\begin{array}{l}\text { Application } \\
\text { of incentive }\end{array}$} & $\begin{array}{l}\text { Import } \\
\text { planning }\end{array}$ & \multirow[t]{2}{*}{ Approval } & $\begin{array}{l}\text { Customs } \\
\text { Facility Affair }\end{array}$ & $\begin{array}{l}\text { Customs } \\
\text { Settlement }\end{array}$ & $\begin{array}{l}\text { Customs } \\
\text { Service } \\
\text { Office }\end{array}$ & $\begin{array}{l}\text { Customs } \\
\text { Secretary }\end{array}$ \\
\hline & $\begin{array}{l}\text { Import } \\
\text { facility } \\
\text { application }\end{array}$ & & $\begin{array}{l}\text { Application } \\
\text { from technical } \\
\text { institution }\end{array}$ & & & \\
\hline \multirow{2}{*}{$\begin{array}{l}\text { Importation } \\
\text { process }\end{array}$} & & & & & Importation & \\
\hline & & & & & $\begin{array}{l}\text { Assessment } \\
\text { of Customs } \\
\text { duty facility }\end{array}$ & \\
\hline \multirow[t]{3}{*}{$\begin{array}{l}\text { Facility } \\
\text { settlement }\end{array}$} & & & $\begin{array}{l}\text { Submission of } \\
\text { import } \\
\text { declaration and } \\
\text { customs } \\
\text { payment receipt }\end{array}$ & $\begin{array}{l}\text { Submission } \\
\text { of import } \\
\text { declaration } \\
\text { and } \\
\text { customs } \\
\text { payment } \\
\text { receipt }\end{array}$ & & \\
\hline & & $\begin{array}{l}\text { Submission } \\
\text { of import } \\
\text { declaration } \\
\text { and customs } \\
\text { payment } \\
\text { receipt }\end{array}$ & & & & $\begin{array}{l}\text { Submission } \\
\text { of import } \\
\text { declaration } \\
\text { and customs } \\
\text { payment } \\
\text { receipt }\end{array}$ \\
\hline & & Approval & & & & \\
\hline
\end{tabular}

Source: Directorate General of Customs and Excise of Republic of Indonesia (2013)

The process shall be conducted by the government to grant customs incentives is as followed:

TABLE II. The Budgeting PROCESS AND DRAFTING OF CUSTOMS DUTY INCENTIVES

\begin{tabular}{|c|c|c|c|}
\hline $\begin{array}{l}\text { Government } \\
\text { (Ministry of } \\
\text { Finance and } \\
\text { Parliament) }\end{array}$ & $\begin{array}{l}\text { Ministry of } \\
\text { Industrial } \\
\text { Affair }\end{array}$ & $\begin{array}{l}\text { Fiscal Policy } \\
\text { Office }\end{array}$ & $\begin{array}{l}\text { Ministry of } \\
\text { Finance }\end{array}$ \\
\hline $\begin{array}{l}\text { Drafting of Annual } \\
\text { Budget Revenue } \\
\text { and Expenditure } \\
\text { Assessment and } \\
\text { discussion amount } \\
\text { of incentives } \\
\text { planning }\end{array}$ & $\begin{array}{l}\text { Technical } \\
\text { assessment based } \\
\text { on industry } \\
\text { activities growth } \\
\text { Analysis of } \\
\text { incentives needed } \\
\text { by business sector } \\
\text { from the data of } \\
\text { incentive } \\
\text { realization in the } \\
\text { latest year }\end{array}$ & $\begin{array}{l}\text { Regulation } \\
\text { drafting } \\
\text { Directorate with } \\
\text { Budget Affair and } \\
\text { Directorate } \\
\text { General } \\
\text { Customs } \\
\text { Excise }\end{array}$ & $\begin{array}{l}\text { Stipulation and } \\
\text { release of customs } \\
\text { incentive } \\
\text { procedure }\end{array}$ \\
\hline
\end{tabular}

Source: Directorate General of Customs and Excise of Republic of Indonesia (2013)

Examining both process shall be passed by government and business that is quite complicated and inefficient. A series of procedure process that takes a lot of time to reduce the business attraction to apply for since the dwelling time need to carry out imported goods which are granted incentives from the port to the warehouse before the settlement of importation documents negatively affect factory activities. The government tried to monitor the use of incentive by using kinds of documents examination in several institutions as instruments however that way of monitoring hinders the business to optimize the incentives thus the government tries to create new incentives scheme that probably will be more effective and potentially can reduce logistic cost by establishing Bonded Logistic Centre.

\section{PERSPECTIVE SUPPLY-SIDE TAX POLICY IN OPTIMIZING BONDED LOGISTIC CENTRE TO PROMOTE THE DEVELOPMENT OF MARITIME INDUSTRY}

Microeconomic policy for at least in this last decade has become important determinant of output and economic growth as catalyst in economy stagnation and economic aggregates. The microeconomic perspective also become antecedent in classical economics in modern era [12]. Since 1981, the mainstream of occupying macroeconomics to boost the growth has been questionable. The Reagan economist has begun to combined macroeconomic policy with supply-side element to favor climate for investment [13].

That policy for most of the cases are related to incentive instruments that likely show the positive movement when the market is suppressed [14]. The intended incentives are varying as long as they are related to the source of economic growth for example deregulation or the change of legislation or particular level of government capital spending. The government capital expenditure is used to improve existing, create new program for example infrastructure to ease the mobility of factor of production. Supply side policy may also be associated to the increasing of productivity by raising output per factor input or efficiency by reducing average cost of production through keep the firm produces goods which its cost close to marginal cost. Importantly, this policy is regarded to be long-term effective policy [15]. Among types of supply side policy, increasing incentives seem become more popular by lowering marginal rate of income tax paid by individual or corporate to encourage the firm and employee to increase output.

Taxation seem has become common instrument in supplyside policy that may be called as supply-side tax policy. The supply-side tax policy that probably has been known or generally identified with tax cuts or other tax incentives can be defined in wider perspective. It means there are many other form of tax policy that give larger space for policy that needs to reconstruct to hinder the policy from being trapped into tax incentive polemic. Considering its coverage, the concept of supply-side tax policy can be reconstructed through deregulation. In practice for example, the deregulation of tax policy can minimize tax dispute that leads to cost reduction of bureaucratic hassle between government and business in the settlement of tax obligation. The termination of unfavorable tax provision that lead to business cash-flow distortion also can be categorized as supply-side tax policy. Probably to some extent, these type of policy is preferable than that of reducedrate tax related instrument [16].

In offering incentives for business, the Indonesian government seem tries to promote new type of fiscal incentives other than to offer conventional tax incentives like VAT exemption and non-collectible customs duty which bear new high administrative cost and inefficient incentives package. As a new of tax incentives, the existence of Bonded Logistic Centre is one emerging economic stimuli package to improve the competitiveness of industry since it will reduce 
the logistic cost that highly affects the selling price and added by types of tax and customs incentives which also reduce the business burden. The BLCs become the stockpiling to collect the inventories in the vast quantity from foreign countries to be used by local manufacture. The local manufacture industries have not had to import material, equipment, supplies for their factory activities [17]. In short BLC is to shorten of procurement chain for manufacture industries since they don't have to import equipment, inventory, machinery, spare parts or other goods needed for their industrial activities.

TABLE III. THE ILLUSTRATION OF SUPPLy CHAIN AFTER IMPLEMENTATION BLC

\begin{tabular}{|c|c|}
\hline Non BLC & BLC \\
\hline Country Origin & Country Origin \\
Raw material supplier & Raw material supplier \\
$\downarrow$ & $\downarrow$ \\
Grading Warehouse & Grading Warehouse \\
$\downarrow$ & $\downarrow$ \\
Distribution center & Distribution center \\
\hline Middle Country & No chain \\
Regional Distribution Centre & \\
\hline Destination Country & Destination Country \\
Distribution Center & Distribution Center \\
$\downarrow$ & $\downarrow$ \\
Buyer & Buyer \\
\hline
\end{tabular}

Source: Indonesia Bonded Logistic Centre Management (2016)

In China, the application of BLC has been practices for types of industry other than manufacture, for instance crossborder e-commerce since 2012 in several cities and property industry since 2013. Mix product needed from overseas are imported and stored in BLC. The variety of imported goods depend on the local buyer industry's forecasting and the trend of market. The importers are responsible to deal with tax and state levies obligation. For most of domestic industry, more than $60 \%$ of material imported are acquired from BLC. This BLC model has shown significant advantage for local buyers and customs. The delivery time and logistic cost have reduced and the imported goods got protection from importer with certain of import services. This system also reduces the burden of customs officer because less frequent of direct import from local business and in the same time it reduces the potential of untaxed goods entering the country [18]. China customs authority has set Import Export Management System to simplify the importation process and to reduce logistic cost even though this facility is focused on temporarily goods for processing in a large storage thus tax obligation and customs duty are postponed. Having processed, the products that will be exported can be stored in BLC under Customs Management System [19]. The bonded storage operational method and management tools model in China is as follow

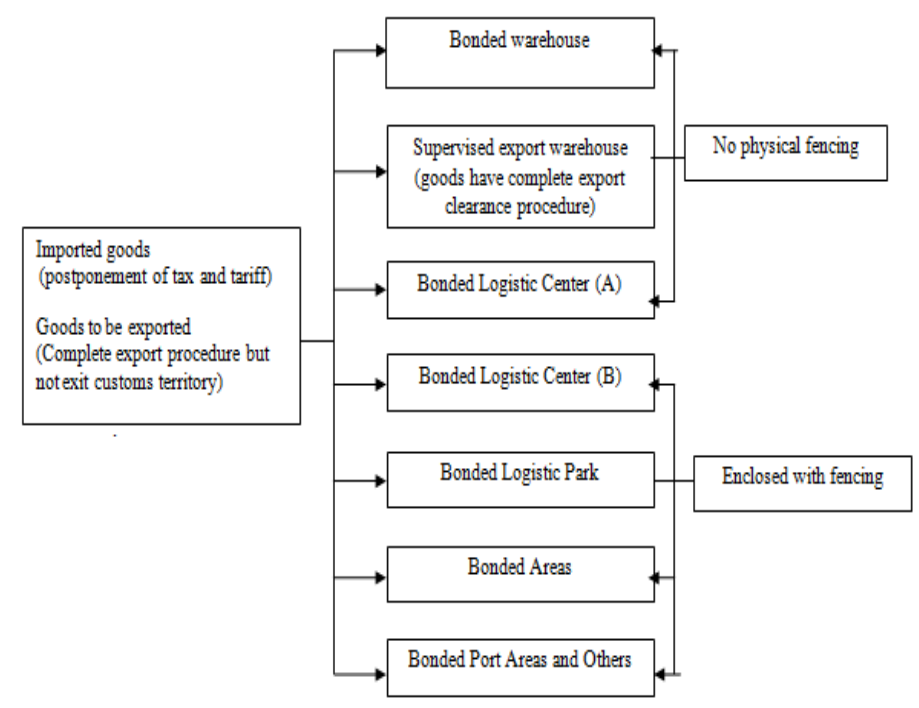

Fig. 1. Bonded Storage Operational Method and Management Tools Model in China

Source: China Customs Institution

The initiation to established BLC in Indonesia is to ensure that industry demand on goods on their business process are available with more competitive logistic cost, less administrative burden and in the same time as realization of tax incentive to support the increase of business competitiveness. The provision of BLC in Indonesia has been regulated in Government Regulation No. 85/2015 (GR-85) concerning Bonded Storage [20]. Through GR-85, the government provide fiscal incentives in the form of (i) postponement of import duty, (ii) non-collection of VAT, luxury-goods sales tax (LST) and prepaid income tax art.22 and (iii) exemption of excise. For the technical regulation, the government has released Ministry of Finance Regulation No. 272/PMK/04/2015 (PMK-272) concerning Bonded Logistic Centre (BLC) [21]. PMK-22 defines BLC is a place for bonded storage which may also conduct one or more simple activities that are not processing activities which generate new products that have a different nature characteristics, and/or function from the original goods, within a certain period for later removal.

In practice, for one BLC will stock one supply chain of particular industrial supplies and the distribution chain of one BLC is expected to supply several industries located in/or out of bonded zones. Thus, the purpose of BLC establishment is to provide flexibility to business to take their goods specifically for manufacture industry that enable them to stockpile their inventory in more cost effective. The chain of BLC as published by Directorate General of Customs and Excise is as followed: 

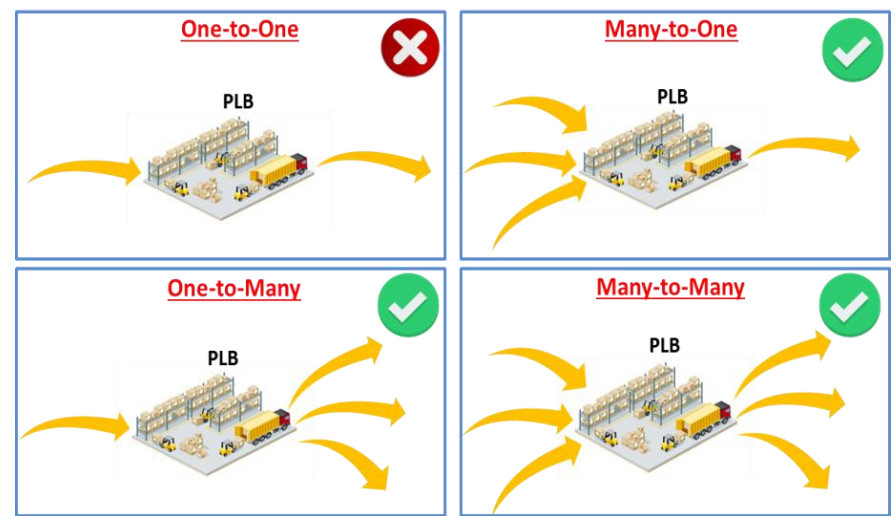

Fig. 2. The Supply Chain Illustration of Indonesia BLC

Source: Directorate General of Customs and Excise (2016)

The government set the plan to established 25 BLC and 14 out of 25 has been established to supply the needs of types of industries including maritime industry chain. The location of BLC in Indonesia following the operator of BLC is as follow:

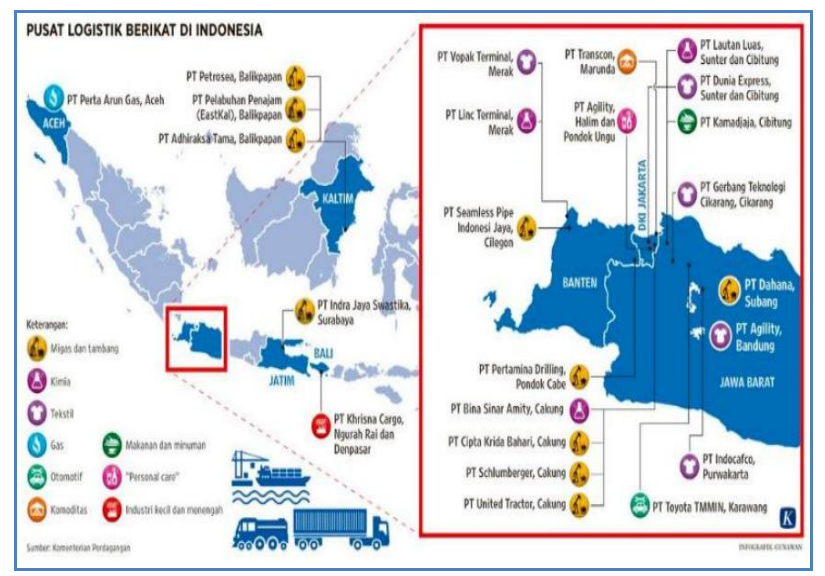

Fig. 3. Bonded Logistic Centre in Indonesia

Source: Directorate General Customs and Excise (2016)

BLC as a multi-functional logistic warehouse that is exempted from import tax and duty, is also intended to promote Foreign Direct Investment. This facility is expected can support industrial estate as the investment location that most of area near with port and toll road. As part of incentive package, the time limit for stockpiling goods in the bonded logistic centre is three years and for certain goods including goods needed by shipping industry chain, the time limit can be extended. The following are tax facilities offer to business who acquire their supplies from BLC.

TABLE IV. TAX AND CUSTOMS FACILITIES ON TRAFFIC OF GOODS TO A BLC

\begin{tabular}{|l|c|c|c|c|}
\hline \multirow{2}{*}{ BLC Facilities } & \multicolumn{3}{|c|}{ Taxes on Imports } & $\begin{array}{c}\text { VAT/LST } \\
\text { on local } \\
\text { deliveries }\end{array}$ \\
\cline { 2 - 5 } & $\begin{array}{c}\text { VAT/LST/Art.22 } \\
\text { Inc } \text { Tax }\end{array}$ & $\begin{array}{c}\text { Import } \\
\text { Duty }\end{array}$ & Excise & - \\
\hline $\begin{array}{l}\text { Import of goods } \\
\text { from overseas }\end{array}$ & Not collected & Postponed & Exempted & \\
\hline
\end{tabular}

\begin{tabular}{|c|c|c|c|c|}
\hline \multirow{2}{*}{ BLC Facilities } & \multicolumn{3}{|c|}{ Taxes on Imports } & \multirow{2}{*}{$\begin{array}{c}\text { VAT/LST } \\
\text { on local } \\
\text { deliveries } \\
\end{array}$} \\
\hline & $\begin{array}{c}\text { VAT/LST/Art.22 } \\
\text { Inc Tax }\end{array}$ & $\begin{array}{c}\text { Import } \\
\text { Duty }\end{array}$ & Excise & \\
\hline $\begin{array}{l}\text { Delivery of } \\
\text { goods originated } \\
\text { from overseas } \\
\text { via: } \\
\text { a. other bonded } \\
\text { stockpiling } \\
\text { area; } \\
\text { b. other special } \\
\text { zones; or } \\
\text { c. other places } \\
\text { within the } \\
\text { Indonesian } \\
\text { customs area } \\
\text { by a taxpayer } \\
\text { granted with } \\
\text { tax and } \\
\text { customs } \\
\text { facilities }\end{array}$ & Not collected & Postponed & Exempted & $\begin{array}{c}\text { Not } \\
\text { collected }\end{array}$ \\
\hline $\begin{array}{l}\begin{array}{l}\text { Delivery of } \\
\text { goods from } \\
\text { another BLC }\end{array} \\
\end{array}$ & Not collected & Postponed & Exempted & $\begin{array}{c}\text { Not } \\
\text { collected }\end{array}$ \\
\hline $\begin{array}{lr}\begin{array}{l}\text { Delivery } \\
\text { goods }\end{array} & \begin{array}{r}\text { of } \\
\text { from }\end{array} \\
\text { other place } \\
\text { within the } \\
\text { Customs Area } \\
\text { (for export or } \\
\text { certain } \\
\text { purposes) } \\
\text { directly to BLC } \\
\text { or via other } \\
\text { bonded } \\
\text { stockpiling area } \\
\text { or other special } \\
\text { zones }\end{array}$ & - & - & - & $\begin{array}{c}\text { Not } \\
\text { collected }\end{array}$ \\
\hline
\end{tabular}

Source: PwC Indonesia Tax Flash Nov 2016 No.20

Before the establishment, the government has established industrial area for example Free Trade Zone, Bonded Zone or Bonded Warehouse. Most of them are intended for export oriented product. In order to optimize the development of industrial sector especially for maritime supply chain industry, the government establishes Bonded Logistic Center as the more comprehensive solution to support the business. Bonded Logistic Center is a multipurpose logistic warehouse that enjoys the exemption of import duty and tax. The different between BLC and others are as follow.

TABLE V. THE DIFFERENT BETWEEN BONDED WAREHOUSE, BONDED ZONE AND BONDED LOGISTIC CENTRE

\begin{tabular}{|c|c|c|}
\hline Bonded Warehouse & Bonded Zone & Bonded Logistic Center \\
\hline $\begin{array}{l}\text { A structure or building } \\
\text { in where imported } \\
\text { goods are kept for } \\
\text { further factory process } \\
\text { within a certain period } \\
\text { of time } \\
\text { Types of bonded } \\
\text { warehouse: } \\
\text { 1. bonded warehouse } \\
\text { for imported goods } \\
\text { distributed to }\end{array}$ & $\begin{array}{l}\text { An area where } \\
\text { imported goods } \\
\text { and/or goods from } \\
\text { other location in } \\
\text { Indonesia are kept to } \\
\text { process for mainly } \\
\text { export purpose }\end{array}$ & $\begin{array}{l}\text { A place to store imported } \\
\text { or domestically produced } \\
\text { goods for a period of time } \\
\text { when they on packaging } \\
\text { process, sorting, } \\
\text { standardization, kiting, } \\
\text { reassembling or repair, } \\
\text { labeling before being } \\
\text { extracted for specific } \\
\text { purpose such as delivery } \\
\text { to another bonded storage } \\
\text { area, used by industry, }\end{array}$ \\
\hline
\end{tabular}




\begin{tabular}{|c|l|l|}
\hline Bonded Warehouse & Bonded Zone & Bonded Logistic Center \\
\hline industrial companies \\
(specifically for \\
manufacture, mining, \\
heavy equipment and & & export or re-export. \\
oil services industry) & & $\begin{array}{l}\text { Goods may be stored for } \\
\text { up to three years although }\end{array}$ \\
2. bonded warehouse & & certain goods are eligible \\
used as distribution & & for extension such as \\
center for duty-free & & goods for mining, oil and \\
stores gas operation and specific \\
3. bonded warehouse \\
for goods for the \\
exported purpose
\end{tabular}

Perspective of supply side policy on economic growth is to provide favorable environment for business. Even though the government has provided conventional incentives like reduce rate of tariff and non-collected VAT, however on business perspective it is not efficient. Deregulation of existing regulation with breakthrough to find new solution is the basic principle of supply-side tax policy. If the government offer reduce tariff until $0 \%$ for imported goods through acquisition of supply taken by shipyard from BLC, the economic benefit they get due to $0 \%$ tariff (see the illustration) can be utilized to expand the business.

TABLE VI. THE ILLUSTRATION OF ECONOMIC IMPACT OF CUSTOMS DUTY/TARIFF ON IMPORTED GOODS FOR SHIPPING INDUSTRY

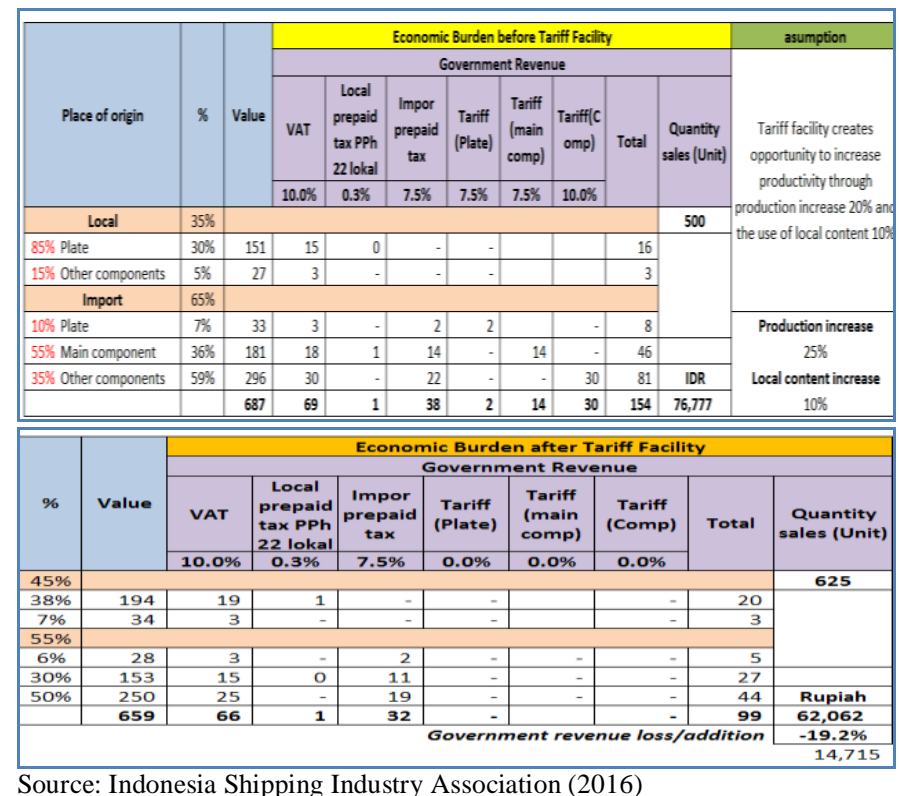

Source: Indonesia Shipping Industry Association (2016)

Based on that illustration, there is potential loss of government revenue from taxation about $19,2 \%$ but customs duty incentive can increase production opportunity and productivity through the increase of production volume up to $20 \%$ and the use of local content up to $10 \%$. The increase of production is intended to be a main supplier of domestic shipping industry. The positive impact of customs duty incentive can also increase shipyard revenue and government potential revenue through corporate income tax as illustrated below.
TABLE VII. THE ILLUSTRATION IMPACT OF CUSTOMS DUTY INCENTIVE ON THE INCREASE AND GOVERNMENT REVENUE FROM CORPORATE INCOME TAX

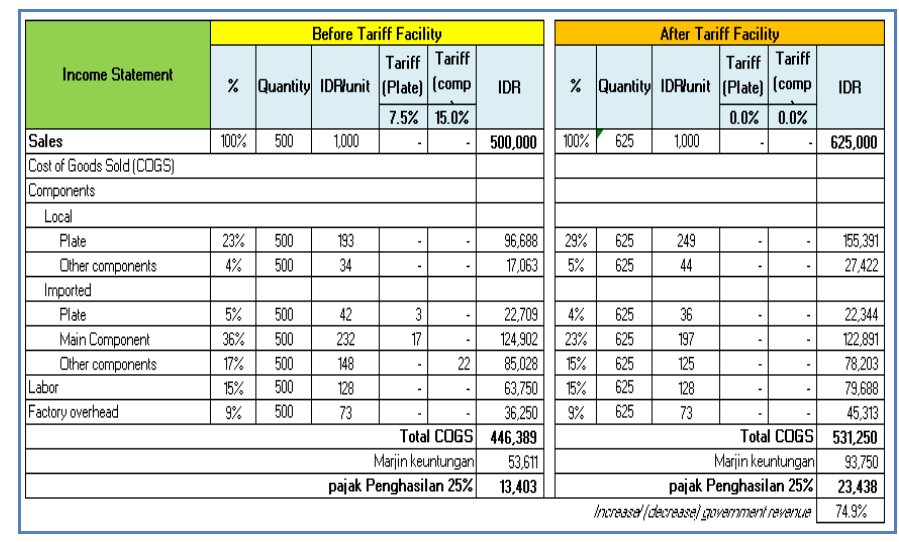

Source: Indonesia Shipping Industry Association (2016)

The illustration above is the impact of partial incentive which use customs duty facility as instrument. The illustration of potential productivity increase when the government offers fiscal incentives package in BLC is as followed:

TABLE VIII. THE ILLUSTRATION OF POTENTIAL PRODUCTIVITY INCREASE OF FISCAL INCENTIVES PACKAGE IN BLC

\begin{tabular}{|l|r|}
\hline Remarks & IDR \\
\hline Cost Insurance Freight (10 unit @ 100) & 1,000 \\
\hline Import duty (15\%) & 150 \\
\hline Cost of imported goods & 1,150 \\
\hline VAT of imported goods (10\%) & 115 \\
\hline Prepaid tax art 22(7.5\%) & 86.25 \\
\hline Total Cost & 1,351 \\
\hline
\end{tabular}

The state levies contribute up to more than $30 \%$ of component material production. If the government give incentives through non-collected tax and other state levies, it means the business can afford to purchase 3 additional unit of goods or the amount can be allocated to improve other factory's activity. In addition, the establishment of BLC will reduce the logistic cost up to $7 \%$ because the shorter of supply chain that means the cost of production will also reduce thus the products produces of local business can offer competitive price especially for those that will be exported.

Besides the monetary cost or tangible cost, the perspective of supply-side tax policy that also promote the deregulation to ease the business is also important to reduce intangible cost. The cost to deal with carry out imported goods from the stockpiling in the port and to settle the import declaration and related document will also diminish since this part will become the responsibility of BLC management.

\section{CONCLUSION}

The government has shown its serious effort to support the development of shipyard industry productivity by offering conventional fiscal incentives with the form of customs duty paid by government and non-collectible VAT. Of course, the government shall establish the instrument to monitoring the realization of incentives whether it has been utilized properly 
as its goal. However, the conventional fiscal incentive bear new burden for instance administrative burden for business to fulfill their obligation thus the incentives seems contraproductive with its aim. As the follow up of the government support on industrial development, the government establish one package incentive through the establishment of Bonded Logistic Centre (BLC). The BLC currently can reduce the cost of production due to non-collected customs duty, VAT and logistic cost. In addition, it also offers less administrative burden for business since the import settlement will not the responsible of the buyer but it will shift to the management of BLC.

\section{REFERENCES}

[1] Ministry of Industrial Affair of Republic of Indonesia. (2015). When the dock ship bites the finger (Saat dok kapal gigit jari). February 2017. http://www.kemenperin.go.id/artikel/9258/Saat-Dok-Kapal-Gigit-Jari

[2] World Bank. (2016). Logistic Performance Index in ASEAN 2007 2016. February 2017. https://lpi.worldbank.org/international/global

[3] Coordinating Ministry of Economic Affair of Republic of Indonesia. (2015, November). Recovering and Strengthening the Foundation for Sustainable National Economic Growth (Memulihkan dan Memperkuat Landasan Bagi Kenaikan Pertumbuhan Ekonomi Nasional yang Berkelanjutan). Paper presentation at Jakarta Convention Centre.

[4] Pricewaterhouse Coopers Tax Flash. (2015, October). Tax Flash 2015 $\begin{array}{lll}\text { No. } & 26 . & \text { February }\end{array}$ https://www.pwc.com/id/en/taxflash/assets/english/2016/taxflash-201603.pdf

[5] UNCTAD. (2000). Tax Incentives and Foreign Direct Investment: A Global Survey. New York and Geneva: United Nations Publication. http://unctad.org/en/Docs/iteipcmisc3_en.pdf

[6] Tait, Alan. (1988). Value Added Tax International Practice and Problem. Washington DC: International Monetary Fund.

[7] Government of Republic of Indonesia. (2000). Government Regulation No. 146/2000 on Import and/ or Delivery of Particular Taxable Goods and Delivery of Certain Taxable Services Excluded from Value Added Tax (Impor dan atau Penyerahan Barang Kena Pajak Tertentu dan atau Penyerahan Jasa Kena Pajak Tertentu yang Dibebaskan dari Pengenaan Pajak Pertambahan Nilai). Unpublished.

[8] Government of Republic of Indonesia. Ministry of Finance Regulation No. 193/PMK.03/2015 on Procedures for Provision of Non-Collectible Facilities for Value Added Tax on Import and/ or Delivery of Particular Transport Equipment and Delivery of Taxable Services related to Specific Transport Equipment (Tata Cara Pemberian Fasilitas Tidak Dipungut Pajak Pertambahan Nilai Atas Impor dan/atau Penyerahan Alat Angkutan Tertentu dan Penyerahan Jasa Kena Pajak Terkait Alat Angkutan Tertentu). Unpublished.

[9] Government of Republic of Indonesia. Ministry of Finance Regulation No. 192/PMK.03/2015 on Procedures for the Refund of Value Added Tax that Non-Object of No Value Added Tax Facility (Tata Cara Pembayaran Kembali Pajak Pertambahan Nilai yang Seharusnya Tidak Mendapat Fasilitas Tidak Dipungut Pajak Pertambahan Nilai). Unpublished.

[10] Madzivanyika, Ezera. (2016). Customs Duty Incentives and Their Effects on Customs Revenue Mobilization: The Case of Zimbabwe 2009-2014. Public and Municipal Finance, 5 (1).

[11] Sogema, C. (2013). Tax Exemptions Study Final Report and Briefing Note. Prepared for Ministry of Finance, Tanzania.

[12] Ture, Norman. (1982). Supply Side Analysis and Public Policy. An Essay in Supply Side Economics. Washington DC: The Institute for Research on the Economics of Taxation.

[13] Reynolds, Alan. (1985). Some International Comparison of Supply-side Tax Policy. Cato Journal, 5, 2.

[14] Krueger, Anne. (2010). Increased Understanding of Supply-Side Economics, Reserved Bank of Australia. February 28, 2017. https://www.rba.gov.au/publications/confs/2010/pdf/krueger.pdf
[15] Threadgould, Andrew. (n.d.). How Can Supply-Side Policies be Used to

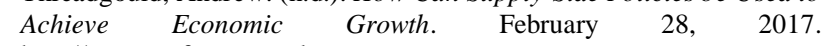
http://www.anforme.co.uk

[16] Rosdiana, Haula. (2008). Reconstruction of Supply-side Tax Policy Concept (Rekonstruksi Konsepsi Supply-side Tax Policy). Jurnal Ilmu Administrasi dan Organisasi, 15 (3).

[17] Setiawan, Budi, and Sangian, Rudi. (n.d.). Supply Chain Indonesia, Bonded Logistics Center vs. Bonded Zone (Supply Chain Indonesia, Pusat Logistik Berikat vs Kawasan Berikat). February 28, 2017. https://supplychainindonesia.com/new/pusat-logistik-berikat-vslogistik-berikat/

[18] Colliers International. (2015). Crossing Border, Changing Time: A New Model for International E-Commerce for China's Bonded Logistic Property Market. February 28, 2017. http://www.colliers.com//media/files/marketresearch/apac/china/white-paper/changingtimes.pdf?la=en-GB

[19] KPMG China. (2016). China Customs Import \& Export Management Basic System \& Operations Implementation. February 28, 2017. http://www.carecprogram.org/uploads/events/2010/CAREC-TrainingShanghai-Customs-College/China-Customs-Import-and-ExportManagement.pdf

[20] Government of Republic of Indonesia. (2015). Government Regulation No. 85/2015 on Bonded Storage (Tempat Penimbunan Berikat). Unpublished.

[21] Government of Republic of Indonesia. (2015). Ministry of Finance Regulation No. 272/PMK/04/2015 on Bonded Zone (Kawasan Berikat). Unpublished. 